\title{
“MERTELU” PROFIT-SHARING AGREEMENT AS THE ATTEMPT TO INCREASE THE INCOME OF TUBEROSE TENANT FARMERS
}

\author{
Nasikh \\ ${ }^{t}$ Department of Economics Development, Faculty of Economics, Universitas Negeri Malang, East \\ Java, Jalan Semarang, Malang 65145, Indonesia \\ E-mail: nasikh.fe@um.ac.id
}

\begin{abstract}
Farmer communities in Pasuruan regency, East Java, still rely on the agriculture sector to generate their income. Tuberose farmers, in particular, find difficulty in dealing with land ownership. They, who are skilful and expert, are lack of capital ownership, especially the land. The majority of tuberose farmers depend on "mertelu" profit-sharing as their daily income alternative. This study aims to analyse "mertelu" profit-sharing as an attempt to increase the tuberose farmers' incomes in Pasuruan regency, East Java. The research is done by a purposive sampling in Bangil, Rembang sub-districts, Pasuruan regency. This study uses a qualitative descriptive approach with the instrument of microeconomic theory. Data are collected by interviews with land owners and the tuberose farmers. The research finding shows that "mertelu" profit-sharing becomes one of the alternatives to increase the tuberose farmers' income. Nevertheless, the tuberose farmers in Pasuruan regency, East Java, feel that "mertelu" profit-sharing has not been able to improve their income significantly.
\end{abstract}

Key words: profit; sharing; farmers; income; tuberose

\section{BAGI HASIL "MERTELU” SEBAGAI UPAYA PENINGKATAN PENDAPATAN PETANI SEDAP MALAM}

\begin{abstract}
ABSTRAK. Pendapatan masyarakat petani di Kabupaten Pasuruan Propinsi Jawa Timur masih mengandalkan pada sektor pertanian. Utamanya bagi petani sedap malam (tuberose) yang masih terkendala kepemilikan luas lahan. Petani sedap malam yang memiliki keahlian dan keterampilan di bidangnya, ternyata tidak diimbangi dengan kepemilikan modal dan khususnya lahan sawah. Sebagian besar petani sedap malam masih mengandalkan bagi hasil "mertelu" sebagai alternatif untuk tetap mendapatkan pendapatan sehari-hari. Penelitian ini bertujuan untuk menganalisis bagi hasil "mertelu" sebagai upaya peningkatan pendapatan petani sedap malam di Kabupaten Pasuruan Jawa Timur. Lokasi penelitian dilakukan secara purposive sampling, yaitu di Kecamatan Bangil dan Kecamatan Rembang Kabupaten Pasuruan. Penelitian ini menggunakan pendekatan deskriptif kualitatif dengan instrumen teori ekonomi mikro. Pengumpulan data dilakukan melalui wawancara kepada pemilik lahan dan petani sedap malam. Hasil penelitian menunjukkan bahwa bagi hasil "mertelu" menjadi salah satu alternatif untuk meningkatkan pendapatan petani sedap malam. Walaupun demikian, bagi hasil "mertelu" yang selama ini dilakukan belum mampu meningkatkan pendapatan secara signifikan bagi petani sedap malam di Kabupaten Pasuruan Jawa Timur.
\end{abstract}

Kata kunci: hasil; bagi; petani; pendapatan; sedap malam

\section{INTRODUCTION}

Indonesia is a country whose major population live off the agricultural sector. The agricultural sector is one of the essential sectors which plays an important role for the economic development, particularly in the rural community (Amin et al., 2017). The majority of rural community work as farmers. However, many of them still find problems related to capital and agricultural land ownerships (Mahon, et al., 2017; Melesse, et al., 2019). This statement is in line with the findings by Bukhori (2014). He explains that our farmers still have minimum capital and agricultural land. In a developing country such as Indonesia, the rural economic development is crucial in achieving the community's well-being. The rural community is one of the vital components of the national development. The major population of Indonesia is rural residents. The economic activities, such as increased earnings and community's wellbeing in a certain period reflect the economic growth of a country (Ryan et al., 2017). In other words, the national economic development is closely related to the local economic development. The success of national economic development can be identified by many indicators, one of them is the regional economic development. The economic growth is an indicator that shows the transformation of economic conduct. Consequently, the economic growth should concern about the improvement of regional development (Purnamasari, 2017). When the regional economic growth rate decreases, it means that the national income drops as well (Putra \& Sutrisna, 2017; Winardi et al., 2017; Nasikh, 2017; Nasikh et al, 2017; Elly et al., 2020; Futum, 2020; Herdiyanti \& Faisal, 2020)Indonesia. There were 49 informants consisting of local government members and people living around forests (or pesanggem farmers. 
The uneven income distribution and focused development in certain areas are two economic problems that have not been resolved yet. Various policies have been established by the Government, but they cannot figure out the never-ending economic issues. The economic development becomes one of the solutions to embrace the economic challenges happening in Indonesia until now. According to Sukwika (2018), one of the challenges is related to the individual or household income, particularly farmers in the rural areas. Pasaribu (2015) stated that the economic development should be able to create wellbeing to all members of the community despite the economic centralization. In addition, the economic development should affect them positively so that there is no decreased income in the rural household. Islami \& Nugroho (2018) explain that some sectors not becoming the focus contributes to the main problem in the regional economic development.

The potential of agricultural sector in Pasuruan regency, especially in Bangil and Rembang subdistricts, is deemed relatively good. It is no longer a secret that tuberose is one of the leading commodities of the agricultural sector in Pasuruan regency, East Java. Data of tuberose production development in Pasuruan regency shows that until the end of 2018, the tuberose production reached $72,473,879$. Those numbers exceed the target that was established by RPJMD of Pasuruan regency in 2013 to 2018 as many as $31,570,783$. It was $19.97 \%$ higher than the expectation. When compared to the production realization in 2017 that was 66,131,361, it increased $6,89 \%$. The increased production is mainly affected by the increased harvested area and the tuberose productivity.

As the leading commodity of Pasuruan regency, the tuberose can drive the economic cycle of Pasuruan regency. The Central Bureau of Statistics of Pasuruan regency in numbers., 2019 (https://pasuruankab.bps. go.id) showed that the average number of decorative plants in Bangil and Rembang sub-districts was $93,752,96$ thousand. It is the local economic resource that is very potential to be developed and becomes the stakeholder's concern.

The development of agricultural sector does not only serve the potential commodity, but it also includes the regional development. It aims to increase tuberose farmers' earnings in Pasuruan regency. However, the development of agricultural sector, especially the tuberose, has not been fully beneficial for the farmers and communities in Pasuruan Regency. It is because the economic resources have not been optimized. The tuberose farmers have not been able to optimize the agricultural sector as the dominant business field that gives big contribution to the farmers' earning.

One of the common problems faced by the skilled tuberose farmer is the absence of capital and agricultural land area. One of the attempts that they can do to survive and make living is profit-sharing agreement with capital and land owners. The profitsharing agreements an alternative to get a job and earn some money for tuberose farmers with no capital or land.

The problems displayed above do not only happen to the farmers in Pasuruan regency, but they also challenge farmers in other cities. Bangil and Rembang sub-districts are two regions with wide agricultural areas and prospective agricultural resource, especially the tuberose as the decorative plant. The tuberose production condition in Pasuruan regency is very prospective, and the land condition is highly supportive. These can be seen from data of tuberose production in Pasuruan regency provided by Department of Agriculture of Pasuruan regency in Table 1 as follows.

Table 1. Tuberose Production in Bangil and Rembang subdistricts, Pasuruan Regency

\begin{tabular}{ccccccc}
\hline \multirow{2}{*}{ No } & Types of Data & \multicolumn{5}{c}{ Year } \\
\cline { 2 - 6 } 1 & $\begin{array}{l}\text { Land width } \\
\text { (Ha) }\end{array}$ & 1,372 & 1,389 & 1,423 & 1,478 & 1,502 \\
\hline 2 & $\begin{array}{l}\text { Production } \\
\text { (millions of } \\
\text { stack) }\end{array}$ & 62,43 & 63,76 & 64,32 & 64,96 & 64,91 \\
\hline 3 & $\begin{array}{l}\text { Productivity } \\
\text { average } \\
\left(\text { stacks } / \mathrm{m}^{2}\right)\end{array}$ & 9 & 8 & 8 & 8 & 9 \\
\hline
\end{tabular}

Source: Department of Agriculture of Pasuruan Regency; data are processed and analyzed, $2020 \mathrm{http}$ ://isperta.pasuruankab.go.id

In regards to the local economic potential and the problems faced by the tuberose farmers in Pasuruan regency, the researcher is interested in reviewing and analyzing 'mertelu' profit-sharing agreement done by the tuberose farmers in Pasuruan regency East Java as the attempt to increase their household earnings.

The objective of this study is to identify the model of 'mertelu' profit-sharing agreement done by the tuberose farmers as the attempt to increase their household earnings. The findings are used as the consideration and reference for the tuberose farmers and related policy makers in the regional government of Pasuruan regency, East Java to develop the tuberose potential in the future.

The literature review of this study is an agreement between the tenant farmers (the tuberose farmers) and land owners with mutually agreed 
sharing. For example, each party obtains a half ('maro') or the tenant farmers obtain one-third or 'mertelu' (Rafly et al., 2016). When analyzed from the viewpoint of Ministry of Agrarian Affairs and Spatial Planning, Director General of Agrarian Management, and Regulation of Minister of Agriculture No. 4 of 1964 about the Establishment of Special Balance in the Implementation of ProfitSharing Agreement, the profit-sharing agreement is legal conducts in which the land owner, due to some reasons, is unable to manage his own land, but he wants to obtain revenue from his land. Therefore, he makes an agreement with other party on which the profit-sharing balance has been mutually agreed by both parties.

The interesting empirical study is the profitsharing model applied by the tuberose farmers in Pasuruan regency, the so-called "mertelu" agreement. This unwritten agreement is a work agreement or bond between the land owner (capitalist) and the tenant farmers who accept the work and tuberose production result. Wages are counted based on the post-harvest product or the agreement when conducting the transaction in the first place. The amount of profit-sharing is reward obtained by the land owner and tenant farmers based on their agreement (Amin et al., 2017; Ditzler et al., 2018; Lubis \& Indrawati, 2017; Cook \& Ludwig, 2019; Appelgren, 2019; Bhosekar \& Ierapetritou, 2018).

The novelty value of this research is "mertelu" profit-sharing agreement between the land owner and the tuberose farmers which is mutually profitable. The tuberose farmers obtained one-third of the profit, whereas the land owner obtains the remaining. This mutually-profitable agreement is a novelty.

"Mertelu" profit-sharing agreement in the agricultural sector is a legal agreement regulated in the community law of Pasuruan regency. It is the agreement between tenant farmers who work on the land and the land owner, in which the profit will be divided in a "mertelu" manner that is mutually profitable.

\section{METHOD}

This study employs a descriptive qualitative approach as a way to obtain data as completely, thoroughly, and intensively as possible about the model of 'mertelu' profit-sharing agreement as the attempt to increase the income of tuberose tenant farmers in Pasuruan regency, East Java. The study takes place in Lumpang Bolong and Pekoren villages in Bangil and Rembang sub-districts, Pasuruan regency. Both villages are intentionally chosen because they are the production central of tuberose in Pasuruan regency. The main informant of the study is the tuberose tenant farmers, whereas the supporting information is obtained from the land owners. The interview is conducted to obtain the primary data from the informants. In addition to the interview, an observation is carried out to investigate the real situation in the research setting. The observation is also used to gain more information about the expenses and incomes. The information is used as the instrument to analyze the income of tuberose tenant farmers in 'mertelu' profit-sharing agreement in Pasuruan regency.

The interview and observation were conducted in January-September 2020. There were 36 informants, consisting of 18 tenant farmers and 18 land owners. Out of 36 informants, 14 were from Bangil sub-district, and 22 were from Rembang subdistrict.

The analysis tool used in this study is the qualitative data with the micro economy instrument. The are four stages of the qualitative data analysis, namely (1) identification of collected data, (2) data selection by data reduction so that it is relevant to the research focus and objective, (3) data explanation as a way to inform the finding scientifically, logically, systematically, and empirically, and (4) decision making and conclusion. In relation to the micro economy instrument, the cost theory, production function, and consumption function are used.

The cost function of tuberose production (Golosnoy \& Rossen, 2018; Cook \& Ludwig, 2019; Appelgren, 2019; Bhosekar \& Ierapetritou, 2018; Brady et al., 2017; Brooker et al., 2015) is as follows equation (1).

$\mathrm{TC}=\mathrm{FC}+\mathrm{VC}$

Note:

TC: total cost during the tuberose business activities

FC: fixed cost during the tuberose business activities

VC: variable cost

The consumption function of tuberose production (Golosnoy \& Rossen, 2018; Cook \& Ludwig, 2019; Beykal et al., 2018a;. Beykal, et al., 2018b); Bhosekar \& Ierapetritou, 2018; Brady et al., 2017; Brooker et al., 2015; Osama et al., 2017) is as follows equation (2).

$\mathrm{TR}=\mathrm{P} . \mathrm{Q}$

Note:

P: price of a tuberose

Q: quantity of tuberose

TR: total revenue 


\section{RESULTS AND DISCUSSION}

The research findings showed that there were two factors driving the tuberose tenant farmers and the land owners to implement 'mertelu' profit-sharing agreement: age and energy. The land owners were elderly, so they were no longer able to manage their land. This was stated by two land owners who were interviewed, namely Mr. H. Mansyur and Ms. Hj. Saadah. Unlike them, another land owner named Mr. Heru had a different reason. He chose to establish an agreement with the tuberose tenant farmers because he was busy so that he did not have time to cultivate the tuberose on his own land. He had another job.

Meanwhile, the main informant from the tuberose tenant farmer aspect was Mr. Sutoyo. He explained that he was willing to agree on 'mertelu' profit-sharing agreement because he would like to gain higher income in spite of not owning an agricultural land. From the interview with other tuberose tenant farmers, it was revealed that most farmers did not have the agricultural land. Before becoming the tenant farmers, they were day labors and temporary workers. As a result, they did not earn fixed income. Most of them also described that their farming skill was inherited from their parents who worked as farmers as well. In addition, their education background was elementary school. Consequently, their knowledge and skill were limited which made them unable to compete in the working world. Their poor capability made them think as if they were barely able to get a job other than farmers. This condition became one of the factors influencing the tuberose tenant farmers to comply with 'mertelu' profit-sharing agreement.

'Mertelu' profit-sharing agreement implemented by the tuberose tenant farmers and the land owners was basically beneficial for both parties. In Javanese language, 'mertelu' meant one-third, because the tuberose seed was from the land owner. It meant that the ratio of 'mertelu' profit-sharing agreement was 1:2. Two-third of the profit was gained by the land owners and the rest was for the tuberose tenant farmers. From the interview, it was identified that the land owners and tuberose tenant farmers were likely to compromise with 'mertelu' profit-sharing agreement because both parties would mutually bear the loss and profit. They also stated that 'mertelu' profit-sharing agreement was beneficial in terms of cost, due to the fact that the costs of seed, fertilizer, and pesticide were on the land owner, whereas the tuberose tenant farmers provided their energy and skill to manage the land. One of the land owners, Mr. Adenan, listed two advantages of 'mertelu' profit-sharing agreement: utilizing the local labors and guaranteeing maximum productivity of the local labors. The farmer productivity was maximum because the tuberose tenant farmers did not want to get low income, so they would work hard. From Mr. Sinhaji's point of view, another tuberose tenant farmer, 'mertelu' profit-sharing agreement was a blessing for him as it gave him a fixed job that could improve his and his family well-being. In addition, he mentioned that he did not have to think about the operational cost. It was very beneficial as the capital and land ownership were two components that he lacked of.

From the observation and interview, it was revealed that 'mertelu' profit-sharing agreement gave a lot of advantages for both the tuberose tenant farmers and the land owners. The land owners stated that they could obtain higher income when applying it than when implementing other agreements. In addition, it has been widely used by the farmers in Pasuruan regency since many years ago and it was inherited from one generation to the next generation.

From years ago, this agreement has never been a written consent. Rather, it was done orally with both parties trusting each other. The term of the agreement was not defined clearly as well. Based on the interview result, all tuberose tenant farmers and the land owners have been familiar with the model and kept in faith in each other.

Despite its advantages, 'mertelu' profit-sharing agreement also encountered problems and obstacles. Mr. Rudi, another tuberose tenant farmer, explained that one of the problems that the farmers generally faced was the pest that made them find difficulty in the maintenance process. When it occurred, the land owner should spend more money on the pesticide and the tuberose tenant farmers should work longer hours to solve the problem. This problem made the land owner complained about higher capital to spend as they had to buy the pesticide and pay higher for the labor. From the farmers' viewpoint, the problem with them pest made them work longer so that they could not find free time to work on another informal sector to add additional source of income for the family. In normal days, most of them were day labors.

According to the interview result, 'mertelu' profit-sharing agreement did not increase the tuberose tenant farmers' income significantly. It was because the land that was cultivated by the farmers had various areas. The wider the land area that they managed, the higher the income gained by both parties. The farmers found that this profit-sharing agreement was more promising. The income that they could earn from previous jobs as the day labors or construction 
workers was not fixed. It was dependent on whether there were calls or not.

Most of the land owner decided to work on the agricultural sector rather than other sectors because their families did the same thing. Therefore, they have been familiar with ways to manage the land. In addition, they also stated that the agricultural sector was simple, so it saved them from thinking about the maintenance process. An environmental factor also played a role. The geographical condition was suitable for agricultural business. Bangil and Rembang subdistricts had fertile soil and good irrigation system. The sub-districts have never experienced drought even if it was a long dry season. The tuberose tenant farmers were also benefitted as they had limited skill and poor education background which made them unable to find other jobs.

One interesting finding from the interview was that the production in the dry season was higher than in the rainy season.

The interview also revealed the detail information of expenses spent by the land owner and tuberose tenant farmers for one harvesting season per $100 \mathrm{~m}^{2}$ land area. It was displayed in Table 2 as follows.

Table 2. The detail information of expenses during one tuberose production

\begin{tabular}{llc}
\hline \multirow{2}{*}{ Type of expense } & \multicolumn{2}{c}{ Total cost } \\
\cline { 2 - 3 } & $\begin{array}{c}\text { The Land } \\
\text { Owner (IDR) }\end{array}$ & $\begin{array}{c}\text { The Tuberose Tenant } \\
\text { Farmer (IDR) }\end{array}$ \\
\hline Seed & 320.000 & \\
Fertilizer & 280.000 & \\
Pesticide & 260.000 & \\
Plant supplement & 130.000 & 280.000 \\
Plough & & 80.000 \\
Planting wages & & 80.000 \\
Harvesting wages & & \\
\hline
\end{tabular}

Source: processed data from the interview result

According to Table 2, there were four types of expenses spent by the land owner. They were as follows (Beykal, 2018a); Beykal, 2018b); Golosnoy \& Rossen, 2018; Cook \& Ludwig, 2019; Bhosekar \& Ierapetritou, 2018; Brady et al., 2017; Brooker et al., 2015; Dudu \& Smeets, 2017; Joodavi et al., 2015). The expenses of land owner:

$\begin{array}{ll}\text { Seed } & =\text { IDR } 320,000 \\ \text { Fertilizer } & =\text { IDR 280,000 } \\ \text { Pesticide } & =\text { IDR 260,000 } \\ \text { Plant supplement } & =\text { IDR } 130,000 \\ \text { Total expenses } & =\text { IDR } 990,000\end{array}$

The expenses of tuberose tenant farmers Plough = IDR 280,000

2 labors for 2-day planting process $=$ IDR 320,000
2 labors for 1-day harvesting process $=$ IDR 160,000

Total expenses

$=\operatorname{IDR} 760,000$

Therefore, the total expenses for a harvesting season was IDR 990,000 + IDR 760,000 = IDR $1,750,000$ per $100 \mathrm{~m}^{2}$ land area. After the total production was reduced by the cost of machine rent, the net income was obtained. One-third of the net income was gained by the tuberose tenant farmers, whereas the land owner acquired two-third of it. Each region had various expenses and net incomes because they were influenced by the soil condition and irrigation system in the area.

There were two types of agreement in the agricultural sector that have been widely used by Indonesian farmers, namely profit-sharing and rental agreements. The first system, profit-sharing agreement, was categorized into several types, such as a half, onethird (or 'mertelu'), and etcetera. The rental agreement had also some categories, namely lease profit-sharing, land rental, hire purchase, tebasan, and so on. The community has been used to address the agreement terms with 'mertelu' or one-third and 'maro' or a half. Darwis (2016) stated that the practice of agricultural sharing has been implemented since many years ago with different terms. For example, the communities in Central Java addressed it as 'maro', while it was 'mertelu' in East Java. It was called differently in West Java: 'nengah' or 'jejuron' and 'memperduai' in West Sumatera. In addition, Minahasa people addressed it 'toyo', whereas in South Sulawesi it was 'teseng', and 'mogarapu pangimba lo tau' or 'mo balandangia' in Gorontalo.

Unlike the land owner, the tuberose tenant farmers were driven by different factors, including wishes to increase more income and the absence of land ownership (Bukhori, 2014). In addition, Rafly et al (2016) explained that there were some reasons underlying the land owner to establish agricultural cooperation. First, they had the wide agricultural area so that they were unable to manage it themselves. The second reason was because the land owner wanted to grow mutual assistance behavior with the tuberose tenant farmers. The last reason was that the land owner would like to gain income without spending their energy and time. Meanwhile, the tuberose tenant farmers were willing to agree on the agreement because they wanted to obtain higher income, but they did not have the agricultural land. Even if they had the land, it was quite narrow so that they still had much time to manage other land.

As per its name, 'mertelu' meant one-third in Javanese language, thus, the ratio of agricultural 
production share between the land owner and tuberose tenant farmers was 1:2. Two-third portion was for the land owner and the tuberose tenant farmers obtained the rest. The tuberose tenant farmers preferred 'mertelu' profit-sharing agreement because it was fairer for both parties than the rental agreement (Sugeng \& Manurung, 2017). In 'mertelu' profitsharing agreement, the tuberose tenant farmers could get higher income when the yield was good, but they and the land owner would mutually suffer from the loss if the agricultural production failed. In the rental agreement, the rental cost was paid in either money or livestock, but it was not allowed to be granted in both money and livestock (Nugraha \& Putri, 2016; Oladokun et al., 2015; Nasikh, 2017Indonesia. There were 49 informants consisting of local government members and people living around forests (or pesanggem farmers; Haryanto et al., 2019; Haryanto et al., 2016; Heriqbaldi et al., 2015; Lohan et al., 2018) resulting farmers prefer to burn the residues in-situ. Paddy residue management is of utmost important as it contains plant nutrients and improves the soilplant-atmospheric continuum. Burning biomass not only pollutes environment and results in loss of appreciable amount of plant essential nutrients. The objectives of the review paper is to access the amount of residue generation, its utilization in-situ and exsitu, emphasize harmful effects of residue burning on human health, soil health and environment of north-west states of India specially in Punjab and Haryana. This paper also discusses the possible strategies, financial and socio-economic evaluation of the paddy residue management technologies and accentuates the assessment of range of potential policy instruments which would offer avenues for sustainable agriculture and environment. Timely availability of conservation agriculture (CA. In his research, Darwin (2016) described that the profit-sharing agreement was better than the rental agreement because the rental agreement was more speculative. Even though the quality of agricultural yield grown in the rented land was uncertain, the rental cost must be paid in advance. Furthermore, Priyadi \& Shiddiqie (2015) stated that most land owners preferred the profit-sharing agreement because they could obtain the yield gradually during the agreement period. They did not feel like hiring the farm workers because of their reluctance to get involve in the land management. Meanwhile, the tuberose tenant farmers chose to establish the the profit-sharing agreement because the land owner wanted to do so.

In the initial agreement, it has been admitted that one-third of the yield was for the tuberose tenant farmers and the land owner obtained twothird. Hamidah, et al (2017) in their research found out similar findings. The agreement was established orally. The profit-sharing agreement was done in the land owner's house witnessed by the tuberose tenant farmers. In fact, the written agreement had less risk than the oral consent. When there was a Default, the tuberose tenant farmers could proceed it legally. However, they did not want to establish the written agreement because it was not common among the communities.

There were some obstacles that the tuberose tenant farmers faced. One of them was the pest. The land owner had to spend more money to resolve this problem. The tuberose tenant farmers were also required to invest their energy because they needed to respray the plants.

The interview also acknowledged that both the land owner and tuberose tenant farmers obtained higher income. The tuberose tenant farmers who previously worked as the day labors had unpredicted income. The land owner opened a better job opportunity for them. This job opportunity would certainly increase their income. The land owner was also benefitted from the profit-sharing system. Their land was well-cultivated, so the yield produced income for them and the tuberose tenant farmers.

Despite the fact that 'mertelu' profit-sharing agreement could improve the tuberose tenant farmers' income, the income was not significant. It was dependent on the land area. If the land area was quite wide, the yielddian was significant. However, when the land area was narrow, the yield would not give notable improvement to the tuberose tenant farmers' income. It was in line with the study conducted by (Lubis \& Indrawati, 2017); Nugraha \& Putri, 2016; Hamidah et al., 2017). stating that there were factors that affected the agreement result, including the farmers' education background, experience, the amount of working capital, and the land area. They gave a significant influence to the agreement result.

With the positive effect of 'mertelu' profitsharing agreement, the implementation of it has met the intention of both parties to improve their household income. The usefulness of human beings was when they put maximum efforts to achieve goals that could benefit other people (Nisa \& Hanifah, 2017; Nugraha \& Putri, 2016; Primada \& Zaki, 2015; Ridlwan, 2016; Defrancesco et al., 2018; Ditzler et al., 2018; Parihal et al., 2016). The human development was deemed good when the development could help the individuals and communities to meet their needs, wishes, hopes, and problems entirely (Nasikh et al., 2015; Dian Putra et al., 2016; Caroline \& Lahindah, 
2017; Indriartiningtias et al., 2017; Kumar et al., 2018; Parihar et al., 2013; Elly et al., 2020; Futum, 2020; Herdiyanti \& Faisal, 2020).

The new research finding is the profit-sharing concept that is based on sincerity and acceptance in the beginning of the production process until the harvest period. The profit-sharing is done by using "mertelu" agreement.

\section{CONCLUSION}

The implementation of 'mertelu' profit-sharing agreement between the land owner and tuberose tenant farmers in Pasuruan regency becomes one alternative to improve the tuberose tenant farmers' income. The tuberose tenant farmers are benefitted by the agreement because they can work based on their skill. Their income increases after the agreement is implemented. Previously, they are day labors or construction labors with uncertain income. Nevertheless, 'mertelu' profit-sharing agreement has not been able to increase the tuberose tenant farmers' income significantly.

Further researches are expected to be able to make "mertelu" agreement a formal agreement (legal as it is in the Law Number 2 of 1960) passed by the government, so both parties will no longer use the old custom inherited from their ancestors.

\section{ACKNOWLEDGEMENT}

In this opportunity, the researcher would like to show his gratitude to the Ministry of Agriculture of Republic of Indonesia for funding and assisting this research. The researcher would also like to thank the Directorate for Research and Community Service of the Ministry of Education and Culture of Republic of Indonesia, the Institute of Research and Community Service, Faculty of Economics of the State University of Malang, East Java Indonesia.

\section{REFERENCES}

Amin, A.S., Mas'ud, E.I. \& Junus, M. (2017). The community Preference towards Community Forest Land Utilization in Lekopancing village, Tanralili sub-district, Maros regency. Journal of Forestry and Community, 9, (2), 131. https://doi.org/10.24259/jhm.v9i2.3098

Appelgren, L. (2019). Optimal auditing of social benefit fraud: a case study. Empirical Economics, 56, (1), 203-231. https://doi. org/10.1007/s00181-017-1356-9
Ari Putra, G.N. \& Sutrisna, I.K. (2017). The Effect of Production and Inflation to Export and Economic Growth in Indonesia. E-Journal of Development Economics of Udayana University, 6, (1), 2165-2194. https://ojs. unud.ac.id/index.php/eep/article/view/34943

Beykal, B., Boukouvala, F., Floudas, C.A. \& Pistikopoulos, E.N. (2018). Optimal design of energy systems using constrained grey-box multi-objective optimization. Computers and Chemical Engineering, 116, 488-502. https:// doi.org/10.1016/j.compchemeng.2018.02.017

Beykal, B., Boukouvala, F., Floudas, C.A., Sorek, N., Zalavadia, H. \& Gildin, E. (2018). Global optimization of grey-box computational systems using surrogate functions and application to highly constrained oil-field operations. Computers and Chemical Engineering, 114, 99-110. https://doi. org/10.1016/j.compchemeng.2018.01.005

Bhosekar, A. \& Ierapetritou, M. (2018). Advances in surrogate based modeling, feasibility analysis, and optimization: A review. In Computers and Chemical Engineering 108, 250-267. https:// doi.org/10.1016/j.compchemeng.2017.09.017

Brady, M., Hristov, J., Höjgård, S., Jansson, T., Johansson, H., Larsson, C., Nordin, I. \& Rabinowicz, E. (2017). Impacts of direct payments - lessons for CAP post-2020 from a quantitative analysis.

Bukhori, M. (2014). The Agricultural Sector towards the Development in Indonesia. https://www.jstor.org/stable/25773512?casa token $=2-3 i$ GLz-4qcAAAAA $\% 3 \mathrm{~A} 1 \mathrm{Ve} 42-$ L b R r kd N S O ow 8 N m Z p I I o Q J F X z R $8 \mathrm{~K}$ e $6 \mathrm{D} \mathrm{d} \mathrm{c} \mathrm{t} \mathrm{y} 11 \mathrm{M} \mathrm{k}-$ J v X 3 k T 260 b I 6 c X t H 9 EW4hz10R4hQGgEWOL0M-6swFfONXK IdRYVZhARKeNqXxIlr8LojXsA\&seq=1\# metadata_info_tab_contents

Caroline, C., \& Lahindah, L. (2017). TheAnalysis and Proposal of Marketing Strategy with SWOT Analysis (Case Study in Small Micro Medium Enterprises of Fish Food Waringin Bandung). JJournal of Management Indonesia, 17, (2), 35. https://doi.org/10.25124/jmi.v17i2.1067

Cook, P. J., \& Ludwig, J. (2019). The social costs of gun ownership: a reply to Hayo, Neumeier, and Westphal. Empirical Economics, 56, (1), 13-22. https://doi.org/10.1007/s00181-018$1497-5$ 
Darwis, R. (2016). Agricultural Profit-Sharing Agreement in Tenant Farmer Community in Gorontalo Regency. Legal Perspective of Islamic Economy. Al-Mizan, 12, (1), 1-25. http://jurnal.iaingorontalo.ac.id/index.php/ am/article/view/122

Defrancesco, E., Gatto, P. \& Mozzato, D. (2018). To leave or not to leave? Understanding determinants of farmers' choices to remain in or abandon agri-environmental schemes. Land Use Policy, 76, 460-470. https://doi. org/10.1016/j.landusepol.2018.02.026

Dian Putra, M., Pambudi Tama, I. \& Puspita Andriani, D. (2016). The Analysis of Tile Material Handling Tool Design by Using Axiomatic House of Quality (AHOQ). Journal of Engineering and Management Industial System, 4, (1), 19-30. https://doi. org/10.21776/ub.jemis.2016.004.01.3

Ditzler, L., Klerkx, L., Chan-Dentoni, J., Posthumus, H., Krupnik, T.J., Ridaura, S.L., Andersson, J.A., Baudron, F. \& Groot, J.C.J. (2018). Affordances of agricultural systems analysis tools: A review and framework to enhance tool design and implementation. Agricultural Systems, 164,20-30. https://doi.org/10.1016/j. agsy.2018.03.006

Dudu, H. \& Smeets K.Z. (2017). Impact of CAP Pillar II payments on agricultural productivity. Publications Office of the European Union, Luxembourg. https://doi.org/https://doi. org/10.2760/802100.

Elly, R., Bobby, R.S., Hendrik, J.N., \& Fitri, A. (2020). Agribusiness Behavior of Mango Farmers in The District of Panyingkiran Majalengka Regencybased on Mango Ownership. Sosiohumaniora - Jurnal Ilmuilmu Sosial dan Humaniora, 22, (2), https:// jurnal.unpad.ac.id/sosiohumaniora/article/ view/25472/13715.

Futum, H. (2020). Analysis Of Equality in Social, Economic And Education in Enggelam Village Muara Wis, District of Kutaikartanegara. Sosiohumaniora 22 (3), https://jurnal.unpad.ac.id/sosiohumaniora/ article/view/26287/14358.

Golosnoy, V., \& Rossen, A. (2018). Modeling dynamics of metal price series via state space approach with two common factors. Empirical Economics, 54, (4), 1477-1501. https://doi.org/10.1007/s00181-017-1267-9
Hamidah, S,N., Amatilah, I. \& Surahman, R.M. (2017). The Analysis of Muzara'ah Agricultural Agreement in Rice Field Cultivation in Bumisakti sub-village, Marapah village, Panjalu sub-district, Ciamis regency. 3, (2).

Haryanto, L.I., Masyhuri, M. \& Irham, I. (2019). The Policy Analysis Matrix in Measuring Competitiveness of Maize Farming System in Marginal Areas. Agro Ekonomi, 29, (2), 244. https://doi.org/10.22146/ae.35964

Haryanto, T., Talib, B. A., \& Salleh, N. H. M. (2016). Technical Efficiency and Technology Gap in Indonesian Rice Farming. 3, (3), 29-38. https://doi.org/10.7160/aol.2016.080303

Herdiyanti \& Faisal, M. A. (2020). The Analysis of Socio-Economic Characteristic Impacts on Child Educationin Rural Households. Sosiohumaniora. 22 (1), https://jurnal. unpad.ac.id/sosiohumaniora/article/ view/24064/12976.

Heriqbaldi, U., Purwono, R., Haryanto, T. \& Primanthi, M.R. (2015). An analysis of technical efficiency of rice production in Indonesia. Asian Social Science, 11, (3), 91102. https://doi.org/10.5539/ass.v11n3p91

Indriartiningtias, R., Subagyo, S. \& Hartono, B. (2017). Knowledge Creation in Small and Medium Industries in the Review of Systematic Study. Scientific Journal of Industrial Engineering, 16, (2), 142. https:// doi.org/10.23917/jiti.v16i2.4882

Islami, F.S., \& Nugroho. (2018). Factors Affecting Inequality in Regions of East Java, Indonesia. Journal of Economics and Management Media, 33, (1). https://doi.org/10.24856/mem. v33i1.564

Joodavi, A., Zare, M., \& Mahootchi, M. (2015). Development and application of a stochastic optimizationmodelforgroundwatermanagement: crop pattern and conjunctive use consideration. Stochastic Environmental Research and Risk Assessment, 29, (6), 1637-1648. https://doi. org/10.1007/s00477-015-1049-х

Kumar, V., Jat, H.S., Sharma, P.C., Balwinder-Singh, Gathala, M.K., Malik, R.K., Kamboj, B.R., Yadav, A.K., Ladha, J.K., Raman, A., Sharma, D.K.\&McDonald,A.(2018).Canproductivity and profitability be enhanced in intensively managed cereal systems while reducing the environmental footprint of production? 
Assessing sustainable intensification options in the breadbasket of India. Agriculture, Ecosystems and Environment, 252, 132-147. https://doi.org/10.1016/j.agee.2017.10.006

Lohan, S.K., Jat, H.S., Yadav, A.K., Sidhu, H.S., Jat, M.L., Choudhary,M., Peter,J.K., \& Sharma,P.C.(2018). Burning issues of paddy residue management in north-west states of India. In Renewable and Sustainable Energy Reviews 81, 693-706. https:// doi.org/10.1016/j.rser.2017.08.057

Lubis, D. \& Indrawati, I. (2017). The Analysis of Tenant Farmers' Income with Muzara'ah Agreement and Factors that Affect it. Maqdis : Jurnal Kajian Ekonomi Islam, 2, (1), 1-19. https://doi.org/10.15548/MAQDIS.V2I1.75

Mahon, N., Crute, I., Simmons, E. \& Islam, M.M. (2017). Sustainable intensification "oxymoron" or "third-way"? A systematic review. In Ecological Indicators. 74, 73-97. https://doi.org/10.1016/j.ecolind.2016.11.001

Melesse, M. B., Berg, M. Van Den, Béné, C., Brouwer, I. D., \& Brauw, A. De. (2019). Improving diets through food systems in low- and middleincome countries: Metrics for analysis. https:// doi.org/10.2499/p15738coll2.133351

Nasikh. (2017). Institutional model and activities of destitute society around forest as an attempt to develop the sustainable and equitable forest in East Java, Indonesia. Periodica Polytechnica Social and Management Sciences, 25, (1), 8-16. https://doi.org/10.3311/PPso.8536

Nasikh., Marinda, A., Mukhlis, I., Witjaksono, M., Utomo, S. H., Handoko., Wahyono, H., Soesilo, Y. H., Moeheriono. \& Santoso, S. (2017). The analysis of the economic growth, minimum wage, and unemployment rate to the poverty level in East Java. International Journal of Economic Research, 14, (13), 127-138.

Nasikh, S., Tri Djatmika RWW, E., Eko Soetjipto, B., \& Isnani, G. (2015). A Model of Affordable and High Quality Education Policy in Tulungagung Regency East Java Indonesia. International Journal of Business and Management, 10, (10). https://doi.org/10.5539/ijbm.v10n10p263

Nisa, F. \& Hanifah. (2017). Islamic Economy Review of Muzara'ah in Tembokrejo village, Muncar sub-district, Banyuwangi regency. Journal of Islamic Economics and Law, 3, (2).

Nugraha, S., \& Putri, J. (2016). Muzara'ahAgreement as An Agricultural Financing Alternative in
Indonesia. In Iqtishodia: Journal of Syariah Economy (Vol. 1, Issue 2). https://doi. org/10.35897/IQTISHODIA.V1I2.66

Oladokun, N.O., Larbani, M. \& Mohammed, M.O. (2015). The problems facing the agricultural sector in Nigeria and the prospect of muzara'ah and supply chain model. Humanomics, 31, (1), 18-36. https://doi. org/10.1108/H-11-2012-0022

Osama, S., Elkholy, M. \& Kansoh, R.M. (2017). Optimization of the cropping pattern in Egypt. Alexandria Engineering Journal, 56, (4), 557566. https://doi.org/10.1016/j.aej.2017.04.015

Parihar, C.M., Jat, S.L. \& Delhi, N. (2013). Energy scenario, carbon efficiency, nitrogen and phosphorus dynamics of pearlmillet -mustard system under diverse nutrient and tillage management practices. African Journal of Agricultural Research, 8, (10), 903-915. https://doi.org/10.5897/AJAR12.810

Parihar, C.M., Jat, S.L., Singh, A.K., Kumar, B., Yadvinder-Singh, Pradhan, S., Pooniya, V., Dhauja, A., Chaudhary, V., Jat, M.L., Jat, R.K., \& Yadav, O.P. (2016). Conservation agriculture in irrigated intensive maize-based systems of north-western India: Effects on crop yields, water productivity and economic profitability. Field Crops Research, 193, 104 116. https://doi.org/10.1016/j.fcr.2016.03.013

Pasaribu, C. M. (2015). Study of Expansion Issue in Medan: Review on the Regional Inequality. Journal of Region and Environment, 3, (3), 151. https://doi.org/10.14710/jwl.3.3.151-162

Primada, B.S., \&Zaki, I. (2015). Contract Mechanism of Cultural-Based Agricultural Land Management in Temu village, Kanor sub-district, Bojonegoro regency. JESTT, 2, (11), 954. https://doi. org/10.20473/vol2iss201511pp954-969

Priyadi, U. \& Shiddiqie, A. (2015). The Implementation of Profit-Sharing Agreement in Rice Field Land, Study in Gamping subdistrict, Sleman regency, Yogyakarta. 15, (1).

Purnamasari, F. (2017). The Economic Growth: Government Investment and Investment Management in Islamic perspective (study in Lampung regencies/ cities). Journal of Indonesian Management., 17, (1), 13. https:// doi.org/10.25124/jmi.v17i1.859

Rafly, M., Natsir, M. \& Sahara, S. (2016). Muzara'ah (Farming Agreement) of Agricultural Land 
according to the study of Islamic law. In Jurnal Hukum Samudra Keadilan 11, (2). https://www.ejurnalunsam.id/index.php/jhsk/ article/view/39

Ridlwan, A.A. (2016). Implementation of Muzara'ah Agreement in Islamic Bank: Alternative To Access Capital Agricultural Sector. . . Iqtishoduna, 7(September).

Ryan, Z.R.A., Istiyani, N. \& Hanim, A. (2017). The Analysis of the Effect of Economic Growth, Number of Workforce, and Regional Minimum Wages to the Educated Unemployment in East Java. E-Journal of Business Economics and Accounting, 4,(2), 187. https://doi.org/10.19184/ejeba.v4i2.5826

Sugeng, U.M. \& Manurung, T. (2017). The Analysis of Ratio of Manual to Automatic Nutrunner by Using Cost \& Benefits Method. JISI : JURNAL INTEGRASI SISTEM INDUSTRI VOLUME, 4(1), 65-72. https://doi.org/10.24853/ jisi.4.1.pp-pp
Sukwika, T. (2018). The Role of Infrastructure Development in the Interregional Economic Inequality in Indonesia. Journal of Regional and Environment, 6, (2), 115. https:/doi. org/10.14710/jwl.6.2.115-130

The Central Bureau of Statistics of Pasuruan regency in numbers. (2019). Statistik Daerah Kabupaten Pasuruan.29. https://pasuruankab. bps.go.id/publication/2019/11/25/ d572dde39c0f3d24419ae7af/statistik-daerahkabupaten-pasuruan-2019.html

Winardi, W., Savio Priyarsono, D., Siregar, H., \& Kustanto, H. (2017). The Manufacture Industry Sector Performance in West Java Based on the Location In and Out of the Industrial Region. Journal of Technology Management, 16, (3), 241-257. https://doi. org/10.12695/jmt.2017.16.3.2 